\title{
Christianizing Ethiopia: Legendary Motherhood in the Story of Frumentius
}

\author{
Bernadette McNary-Zak
}

\section{1 \\ Introduction}

Over forty years ago, the Ethiopian philologist Getatchew Haile published a translation of, and introduction to, the Homily in Honour of St. Frumentius Bishop of Axum from a collection of homilies copied between 1336 and 1340 for the Monastery of Hayq Asțifanos in Wällo, Ethiopia. ${ }^{1}$ The homily includes a version of the story of Frumentius that distinguishes the figure of the Queen in the christianisation of the Aksumite kingdom. If, as the American sociologist Gary Alan Fine writes, "[c]ollective memory is about the past-a past filtered and shaped through the needs of the present," ${ }^{2}$ then how might we evaluate the hermeneutic purchase of the version of the story contained in the homily? A brief exploration of how royal motherhood operates in the homily's version of the story situates its distinct pedagogical and cultural currency in an Ethiopian Christian etiology intending to inform and to shape collective memory, and collective identity, for its 14 th century monastic audience. ${ }^{3}$

1 Getatchew Haile, "The Homily in Honour of St. Frumentius Bishop of Axum (e mmL 1763 ff. $84^{\mathrm{v}}-86^{\mathrm{r}}$ )," Analecta Bollandiana 97, no. 3 (1979): 309. EMML 1763 is one of two extant manuscripts (EMML 8508 is uncatalogued and unedited). See: Gianfranco Fiaccadori, "Sälama (Käśate Bərhan)," in EAe 4 (2010): 484-488. See also: Massimo Villa, "Frumentius in the Ethiopic Sources: Mythopoeia and Text-Critical Considerations," Rassenga di Studi Etiopici, Serie terza, 48, no. 1 (2017): 87-111.

2 Gary Alan Fine, "Rumor, Trust and Civil Society: Collective Memory and Cultures of Judgment," Diogenes 54, no. 1 (2007): 7. On the adaptation of the story of Frumentius see: Villa, "Frumentius."

3 I am grateful to colleagues at the Gender and Medieval Studies Conference (Oxford 2018) and the 2oth International Conference of Ethiopian Studies (Mäqälä 2018) for discussion of earlier drafts of this short essay. I am also grateful to the editors and reviewers of this volume. The story of Frumentius has received considerable scholarly attention. The present preliminary study approaches its reception through a narrow focus on the characterization of the figure of the unnamed Queen in the homily's version of the story making use of Villa's foundational work. The characterization of the Queen has not, to my knowledge, received this type of comparative scholarly assessment. The present study does not include the other ${ }_{14} \mathrm{C}$ manuscript 
A cursory review of some of the earliest variants of the story of Frumentius dated to the period of Roman late antiquity reveals inconsistent treatment of the Aksumite Queen. ${ }^{4}$ The fourth century ecclesiastical historian, Rufinus of Aquileia, claims to have received the story of Frumentius from his subject's childhood companion, Edesius. ${ }^{5}$ However, Rufinus includes the story in his continuation of Eusebius' ecclesiastical history, a section of the work that may have drawn on the earlier ecclesiastical history of Gelasius of Caesarea. ${ }^{6}$ Gelasius and Rufinus both employ a basic two-part structure for the story of Frumentius. The first part of the story describes formative events in Frumentius' early life: Frumentius and Edesius travel abroad with their uncle, they are taken captive when their uncle is killed, and they are placed into service in the Aksumite royal court by the king. ${ }^{7}$ The second part of the story presents subsequent events in Frumentius' adulthood: Frumentius and Edesius remain in their posts when the king dies, they gather a Christian community and, upon

in the Hill Museum and Manuscript Library (EMML 8508), nor does it include discussion of the historical identity of the figure of the Aksumite Queen. Due to linguistic limitations, the present study is based almost entirely on sources available in English and in translation. Future work hopes to incorporate a number of critical studies including, among others: Alessandro Bausi, "La tradizione scrittoria etiopica," Segno e Testo 6 (2008): 507-557; Carlo Conti Rossini, Storia d'Etiopia. Parte Prima. Dalle Origini all'avvento della Dinastia Salomonide (Bergamo: Istituto Italiano d'Arti Grafiche, 1928); Gianfranco Fiaccadori, "Sembrouthes 'gran re' (DAE IV 3 = RIÉth 275). Per la storia del primo ellenismo aksumita," La Parola del Passato 59 (2004): 103-157; Paolo Marrassini, Storia e leggenda dell'Etiopia tardoantica. Le iscrizioni reali aksumite (Brescia: Paideia, 2014).

4 For a comparative chart of the versions of the story in the ecclesiastical histories of this period see: Bruno W. Dombrowski and Franz A. Dombrowski, "Frumentius/Abbā Salāmā: Zu den Nachrichten über die Anfänge des Christentums in Äthiopien," Oriens Christianus 68 (1984): 114-169, especially 151. See also the presentation of the story in: Villa, "Frumentius," 88-89; Fiaccadori, "Sälama (Käśate Bərhan)," 485-486.

5 Rufinus of Aquileia, The Church History of Rufinus of Aquileia: Books 10 and 11, trans. Philp R. Amidon (Oxford: Oxford University Press, 1997), 19. The story of Frumentius is in Book X.910, pages 19-20. See also: David Rohrbacher, The Historians of Late Antiquity (London: Routledge, 2002).

6 Gelasius of Caesarea, Ecclesiastical History: The Extant Fragments with an Appendix containing the Fragments from Dogmatic Writings, eds. Martin Wallraff, Jonathan Stutz and Nicholas Marinides, trans. Nicholas Marinides (Berlin: De Gruyter, 2018), xxxiii-xxxvii. The story of Frumentius is on pages 130-139. Gelasius also credits his version of the story of Frumentius to Edesius. See also the discussion in: Mark Humphries, "Rufinus's Eusebius: Translation, Continuation, and Edition in the Latin Ecclesiastical History," Journal of Early Christian Studies 16, no. 2 (2008): 143-164, especially 150-159.

7 Gelasius of Caesarea, Ecclesiastical History, 130-135; Rufinus of Aquileia, Church History, 19. 
release, they part as Frumentius travels to Alexandria where he accepts episcopal consecration and returns to serve the church in Aksum. ${ }^{8}$

Gelasius and Rufinus both highlight the role of the Aksumite Queen in two key moments of transition in the kingdom. The first moment of transition marks the death of the king. Both ecclesiastical historians indicate that when the king dies leaving an infant son as heir, the Queen appeals to Frumentius and Edesius to remain in the kingdom in order to assist with its administration because of her trust in them and their administrative capabilities. ${ }^{9}$ Only Rufinus includes an additional detail: he explains that the dying king had offered the pair release from service upon his death. ${ }^{10}$ The second moment of transition signals the maturity of the young king. When the young king reaches appropriate age, Frumentius and Edesius leave the kingdom. Here, Rufinus again offers a distinct observation, maintaining that Frumentius and Edesius "executed their trust completely and handed it back faithfully"ll to the royal pair before departing the kingdom.

Writing in the mid fifth century, the ecclesiastical historian Socrates refers explicitly to Rufinus as his source for the story of Frumentius. ${ }^{12}$ Although Socrates relies on Rufinus, he also draws on a number of other sources, perhaps including Gelasius, for his version of the story. ${ }^{13}$ Socrates reinforces an independent feature of the Queen's role from each of these ecclesiastical historians. Like Rufinus (and unlike Gelasius), Socrates contends that when the king dies, he gives Frumentius and Edesius freedom from their service. ${ }^{14}$ For Rufinus and Socrates, the king's promise and Frumentius' renunciation of freedom establish a significant foundation for the work that Frumentius undertakes during his continued service. Frumentius' decision to remain in the kingdom appears to be determined for the greater good of the Aksumite people, the Queen's people, thereby concretizing a specific relationship with the Queen and her son. ${ }^{15}$

8 Gelasius of Caesarea, Ecclesiastical History, 135-139; Rufinus of Aquileia, Church History, 20.

9 Gelasius of Caesarea, Ecclesiastical History, 134-135; Rufinus of Aquileia, Church History, 19 .

10 Rufinus of Aquileia, Church History, 19.

11 Ibid., 20.

12 Socrates Scholasticus, The Ecclesiastical History of Socrates Scholasticus, ed. Andrew Zenos (Grand Rapids: William B. Eerdmans, 1957). The story of Frumentius is in Book I.19, pages $5^{1-52 .}$

13 Gelasius of Caesarea, Ecclesiastical History, xxxvii-xxxix.

14 Socrates, Ecclesiastical History, 52. See above: note 10.

15 On the relationship of queens to sons, see Iris Berger and E. Frances White, Women in Sub-Saharan Africa: Restoring Women to History (Bloomington and Indianapolis: Indiana University Press, 1999), 18-19. 
By elevating Frumentius' choice alongside his intellectual and administrative capability and prowess, both Rufinus and Socrates suggest that Frumentius' efforts to build up spaces for Christian prayer and infrastructure for Christian worship in the kingdom, during the remaining years of continued service to the royal family, receive imperial support. ${ }^{16}$ It is telling that Frumentius is openly Christian and that he is entrusted to stabilize the practice of others who are openly Christian across the kingdom; missionary growth takes place under the oversight of the Queen as her son matures.

Like Gelasius (and unlike Rufinus), Socrates emphasizes that Frumentius and Edesius' release from service is based on their explicit request to leave, their desire to return to their homeland and their permission from the king. ${ }^{17}$ For Gelasius and Socrates, such emphasis reinforces Frumentius and Edesius' submission to the secular, governing authority and status of the now mature king. It also draws attention to the fact that Frumentius' stated desire remains unfulfilled. Upon release, Frumentius travels to Alexandria. When Gelasius indicates earlier in his account that Frumentius and Edesius "were not able to establish altars because they did not possess sacerdotal authority"18 as they work to support Christians in the kingdom, he provides a reasonable explanation for Frumentius' decision. Socrates retains a similar tone of preparation and need that provides implicit reason for Frumentius' acquisition of external ecclesiastical support in Alexandria. ${ }^{19}$ For Gelasius and Socrates, the inclusion of Frumentius' unrealized intent suggests that, while Frumentius' decision to travel to Alexandria may not have been publicized, it was certainly supported given that he returns to preside as bishop over the Christians in their kingdom. The implicit welcome of this initiative is a gesture of ongoing imperial oversight in the development of the Christianization of the kingdom.

It is noteworthy that Rufinus, Gelasius, and Socrates share a single detail: the Queen and her son attempt to dissuade Frumentius and Edesius from departing the kingdom. Imperial pressure recognizes that Frumentius and Edesius have earned a place of importance with the royal family as Christian administrators. ${ }^{20}$

16 Rufinus of Aquileia, Church History, 20; Socrates, Ecclesiastical History, $5^{2}$.

17 Gelasius of Caesarea, Ecclesiastical History, 136-137; Socrates, Ecclesiastical History, $5^{2}$.

18 Gelasius of Caesarea, Ecclesiastical History, 137.

19 Socrates, Ecclesiastical History, 52. On Athanasius in these accounts see also: Villa, "Frumentius," 93 .

20 In contrast, Theodoret of Cyrus erases the Aksumite Queen from his version of the story of Frumentius. See: Philip Schaff, ed., Theodoret, Jerome, Gennadius, and Rufinus: Historical Writings (Grand Rapids: William B. Eerdmans, 1989). The story is found in Book I.22, page 58 . 


\section{From History to Homily}

The Homily in Honour of St. Frumentius Bishop of Axum opens with a clear statement of purpose: to explain the Christianization of Aksum. ${ }^{21}$ The homily uses native terms for the Aksumite Kingdom (i.e. Ag'azi) and its royal family in order to set the story of Frumentius into a particularly Ethiopian Christian context. ${ }^{22}$ Although the version of the story in the homily shares a number of features found in the earlier ecclesiastical histories reviewed above, including a similar structure and sequence of events, ${ }^{23}$ there is a subtle yet salient difference: the identity and influence of the Aksumite Queen in the homily's version centers on the inclusion of a speech act.

Unlike the ecclesiastical histories, in the homily's version of the story of Frumentius the Queen is introduced in relation to several other members of the royal family. ${ }^{24}$ The Queen is further distinguished by her public pronouncement about the status of Frumentius and Edesius, issued immediately following the death of the king; unlike the ecclesiastical histories reviewed above, in the homily the Queen speaks directly to the pair and her wordsissued in a single statement of public pronouncement-are included. ${ }^{25}$ That the Queen is the first main character in the homily's version of the story to speak - and that she speaks as a figure of authority - sharpens her agency and autonomy in the homily. It is she who states in her pronouncement-when Frumentius and Edesius should leave the kingdom. ${ }^{26}$ Because she has requested that the pair remain in service, her pronouncement appears to strain the dead

21 Getatchew Haile, "Homily," 316.

22 Ibid., 310-313. As in the ecclesiastical histories reviewed above, the Aksumite Queen is unnamed in the homily.

23 For discussion of the relationship between the homily and the ecclesiastical histories as well as other sources, see: Getatchew Haile, "Homily," 309-313; Fiaccadori, "Sälama". Villa, "Frumentius," has undertaken the careful work needed to confirm Getatchew Haile's proposal for the homily's use of Socrates' account (see 92-95).

24 Getatchew Haile, "Homily," 317; on the complicated relationship between family members, which appears to include more than one son, see: Getatchew Haile, "Homily," 313. See also: Getatchew Haile, "An Anonymous Homily in Honor of King Hllä Așbäḥa of Axum. EMML 1763, ff. $34^{\mathrm{v}}-35^{\mathrm{v}}$," Northeast African Studies 3, no. 2 (1981), 27; Wolfgang Hahn, "Ezanas and Caleb, the Pair of Saintly Kings," in Proceedings of the Xvth International Conference of Ethiopian Studies (Hamburg 2003), ed. Siegbert Unlig (Wiesbaden: Harrassowitz, 2006), 26o-265; Pierluigi Piovanelli, "The Apocryphal Legitimation of a 'Solomonic' Dynasty in the Kabrä nägäśt-A Reappraisal," Aetheopica 16 (2013): 7-44, especially 17-19.

25 Getatchew Haile, "Homily," 317.

26 Ibid. 
king's decision to free Frumentius and Edesius from service upon his death. ${ }^{27}$ Here, Frumentius and Edesius appear to remain in service in obedience to the Queen's pronouncement, thereby acknowledging an authority of person and of office. ${ }^{28}$

The consequence is an alliance with Frumentius; he and the Queen will share responsibility for key areas of the young king's development. The more explicit nature of this partnership is rendered in the observation that Frumentius struggled with his administrative duties. ${ }^{29}$ Here, Frumentius' administrative weaknesses will serve to showcase the strength of his religious sensibilities and accomplishments. Over time, Frumentius undertakes public religious activities, with others and without any obstacles; Christianity takes shape openly and with imperial support. ${ }^{30}$ Accordingly, when Frumentius and Edesius intend to depart the kingdom, the implication is that they are dissuaded not because of Frumentius' secular influence but, rather, because of his religious impact. ${ }^{31}$ The process of constructing Frumentius as a holy person in the homily's version thereby extends more deliberately beyond Frumentius to the figure of the Aksumite Queen; in the homily, her pronouncement is connected to the growth of the Christian religion in the kingdom. ${ }^{32}$

27 Ibid. This also magnifies the element of choice for Edesius and Frumentius.

28 Ibid.

29 Ibid. See also: Villa, "Frumentius," 104-105.

30 Getatchew Haile, "Homily," 317. This parallels the activities described in Rufinus and Socrates, see above: note 16 .

31 Getatchew Haile, "Homily," 317.

32 There is a considerable body of scholarship on the Christianization of Aksum. Studies include, among others: Erich Dinkler, "New Questions concerning King Ezana of Axum," Études et travaux 9 (1976): 6-15; Steven Kaplan, "Ezana's Conversion Reconsidered," Journal of Religion in Africa 13, no. 2 (1982): 101-109; Stuart C. Munro-Hay, Aksum, An African Civilization of Late Antiquity (Edinburgh: Edinburgh University Press, 1991); Christopher Haas, "Mountain Constantines: The Christianization of Aksum and Iberia," Journal of Late Antiquity 1, no. 1 (2008): 101-126; Stephanie L. Black, "In the Power of the Christian God Christ': Greek inscriptional evidence for the anti-Arian theology of Ethiopia's first Christian king," Bulletin of the School of Oriental and African Studies 71, no. 1 (2009): 93-110; David W. Phillipson, Foundations of an African Civilization: Aksum \& the Northern Horn 10оо $B C-A D$ 1300. Woodbridge: Suffolk Curry, 2012; Pierluigi Piovanelli, "Reconstructing the Social and Cultural History of the Aksumite Kingdom: Some Methodological Reflections," in Inside and Out: Interactions Between Rome and the Peoples on the Arabian and Egyptian Frontiers in Late Antiquity, eds. Jitse H.F. Dijkstra and Greg Fischer (Leuven: Peeters, 2014), 329-350; Rugare Rukini, "Negus Ezana: Revisiting the Christianisation of Aksum," Verbum et Ecclesia 42, no. 1 (2021). DoI: http://dx.doi.org/10.4102/ve.v42i1 .2083 . 
Why might the copyist have attended to a homily containing this version of the story of Frumentius? How might this version align with the monastic community's annual commemoration of Saint Frumentius? An appeal to context may provide an initial direction for future consideration. The homily's version recounts the spread of an imperially, politically, and theologically supported form of Ethiopian Christianity. ${ }^{33}$ By casting Frumentius as a founding father of Ethiopian Christianity, whose efforts were made possible by the religious sympathies of the Aksumite Queen, the homily's version casts an etiology that reinforces an ecclesiastical line of succession and royal legitimacy in the past, an etiology that may inscribe positions embedded in monastic tensions of the present. ${ }^{34}$

The Monastery of Hayq Hsțifanos, located in the Amhara region, operated during a period of religious revival. ${ }^{35}$ Under the Solomonic dynasty of this period, hagiography ( $g \ddot{a} d l$ writing) lauded the struggles and triumphs of prior Christians. ${ }^{36}$ Monasteries like Hayq Gsțifanos were responsible for copying manuscripts "which preserved for later generations the cultural legacy of Aksum." ${ }^{37}$ Donald N. Levine writes that "the differentiation of an autonomous stratum of literati made it possible for monks to diffuse the national religious system far and wide." ${ }^{38}$ As a result, Levine continues, "They could also develop a literary tradition that underlay a more inclusive collective identity." 39 Culturally relevant, this "more inclusive collective identity" might thereby impact not only the monks but their fellow non-monastic Christians in the region.

33 See the discussion of belief legends in: Linda Dégh, "What Is A Belief Legend?" Folklore 107 (1996): 33-46.

34 See above: note 2. See also: Villa, "Frumentius," 99-10o for discussion of the homiletic use of ancient sources.

35 Donald Crummey, "Church and Nation: The Ethiopian Orthodox Täwahedo Church (from the Thirteenth to the Twentieth Century)," in Eastern Christianity, ed. Michael Angold (Cambridge: Cambridge University Press, 2006), 457-487, https://doi.org/10.1017/CHOL 9780521811132.020.

36 Steven Kaplan, "Hagiographies and the History of Medieval Ethiopia," History in Africa 8 (1981): 107-123.

37 Donald Crummey, Land and Society in the Christian Kingdom of Ethiopia: From the Thirteenth to the Twentieth Century (Urbana: University of Illinois Press, 200o), 20.

38 Donald N. Levine, "Evolutionary Grades within Complex Societies: The Case of Ethiopia," in Social Theory and Regional Studies in the Global Age, ed. Said Amir Arjomand (Albany: SUNY Press, 2014), 245.

Ibid. 
The transmission of foundational narratives and legends contributed to this religious revival by hearkening to the past in a purposeful way. In particular, the Kabrä Nägäśt introduced an account of the rise of the contemporary Solomonic dynasty "claiming both the legitimate mantle of the Aksumite rulers and descent from the biblical King Solomon and the Queen of Sheba." ${ }^{40}$ Here, "Solomonic renewal in the state was preceded by renewal in the church, which expressed itself in a vigorous monastic movement." ${ }^{\text {11 }}$ In this context, by recalling the success of missionary growth, the homily's version of the story of Frumentius may have provided ideological support for Christian evangelization and expansion efforts under King 'Amdä Şəyon. ${ }^{42}$ Taddesse Tamrat explains that several monasteries in this period, including several in the Amhara region, "seem to have made a strong bid for influence as champions of better moral standards in the administration of the Church, and in the daily lives of the Christians, including the monarchs themselves." ${ }^{23}$ The Egyptian ecclesiastical authority at this time, Abunä Ya'əqob, created strategic alliances with monastic leaders in the region in an effort to influence religious reform. ${ }^{44}$ More specifically, the power of the royal court thwarted the Abunä's unsuccessful attempts to overturn the practice of polygamy among the king and his successors. ${ }^{45}$

The homily's version of the story of Frumentius admits to a polygamous king who dies with an heir too young to rule independently; as a result, this version repositions the direct authority of the king during a key period in the spread of Christianity in the kingdom. By stabilizing and enhancing the authority of the Aksumite Queen, this version hearkens to a long tradition of rule and regency by Ethiopian queens in the past. ${ }^{46}$ There is, perhaps, a certain irony between a king who ignores reprimands about his un-Christian marital practices and a

40 Crummey, "Church and Nation," 461. See also Steven Kaplan, "Dominance and Diversity: Kingship, Ethnicity, and Christianity in Orthodox Ethiopia," Church History and Religious Culture 89, no. 1 (2009): 291-305; Piovanelli, "The Apocryphal Legimitation"; Iosif Fridman, "The Aksumite Kingdom in the Lives of Aksumite Saints," in Veneration of Saints in Christian Ethiopia: Proceedings of the International Workshop Saints in Christian Ethiopia: Literary Sources and Veneration, Hamburg, April 28-29, 2012, ed. Denis Nosnitsin (Wiesbaden: Harrassowitz, 2015), 51-66.

41 Crummey, "Church and Nation," 461.

42 Ibid., 468.

43 Taddesse Tamrat, Church and State in Ethiopia: 1270-1527 (Oxford: Clarendon Press, 1972), 107.

44 Ibid., 115-118, 178-18o. Taddesse Tamrat provides a dating of c. 1337 for this Abunä (117). See also: Crummey, "Church and Nation," 468-469.

45 Taddesse Tamrat, Church and State, 116-118. See also: Crummey, "Church and Nation," 469.

46 Knud Tage Andersen, "The Queen of the Habasha in Ethiopian History, Tradition and Chronology," Bulletin of the School of Oriental and African Studies 63, no. 1 (200o): 31-63. 
Queen who tolerates the spread of the religion throughout her kingdom over an extended period of time. A Coptic Abunä attempting, unsuccessfully, to purge his king from such pagan practice might see a cautionary tale in the homily's version of the story of Frumentius.

The homily's version also asserts a strong relationship between the Coptic Abunä and the local Christian community. Getatchew Haile draws attention to the significance of this relationship with regard to religious identity when he suggests that "The anonymous author of this homily was a foreigner who had access to local and foreign sources." ${ }^{47}$ This suggestion highlights again the etiological role of the story of Frumentius in this particular context. Steven Kaplan explains that

Athanasius' selection of Frumentius to head the Church in Ethiopia established a precedent whereby the leader of the Ethiopian Church was chosen by the head of the Egyptian (later Coptic) Church until the middle of the twentieth century. The candidates chosen, Egyptian monks and not Ethiopians, arrived in Ethiopia unfamiliar with the local languages and customs and with no indigenous political base. Thus, they were usually dependent on the goodwill of the monarch. ${ }^{48}$

In the homily's version of the story of Frumentius, the Queen's "goodwill" is extended. ${ }^{49}$ She comes to recognize Frumentius as an orthodox Christian figure of authority. Given the evidence that Frumentius' episcopal consecration was contested, ${ }^{50}$ the consequences of the Queen's pronouncement are later reinforced by the homily's use of epithets that exalt Frumentius' status and praise for his activities; these serve to validate the legitimacy of his episcopal appoint-

47 Getatchew Haile, "Homily," 313. See also: Villa, "Frumentius," 97-98.

48 Kaplan, "Dominance and Diversity," 294. For an extended historical treatment, see: Stuart C. Munro-Hay, Ethiopia and Alexandria: The Metropolitan Episcopacy of Ethiopia (Warszawa:ZAŚ PAN, 1997). See also: Alessandro Bausi and Alberto Camplani, "New Ethiopic Documents for the History of Christian Egypt," Zeitschrift für antikes Christentum 17, no. 2 (2013): 215-247, especially 226-230; Getatchew Haile, "Homily," 312 , for discussion of the homily's purpose in relation to this practice.

49 For comparison consider: Getatchew Haile, "An Anonymous Homily in Honor of King Allä Aṣbäha of Axum"; Susanne Hummel, "The Disputed Life of the Saintly Ethiopian Kings 'Abrəhā and 'Aṣbəha," Scrinium 12, no. 1 (2016): 35-72, Dor: https://doi.org/10.1163/18177565 -oo121po6.

50 See Athanasius, Apologia ad Constantium, 31, in Archibald Robertson, ed., Select Writings and Letters of Athanasius, Bishop of Alexandria (Grand Rapids: William B. Eerdmans, 1953), 248-249. 
ment. ${ }^{51}$ Together, the characterization of Frumentius' religious orthodoxy and episcopal legitimacy in the homily could thus define a commissioning whose lineage extends to the Coptic Abunä, possibly lending integrity to a royal reprimand.

The Homily in Honour of St. Frumentius Bishop of Axum recalls a version of the story of Frumentius that not only affirms the influential role of a foreigner on the religious orientation of an Aksumite Queen and her royal family; it also intensifies deliberately her characterization through the inclusion of her speech act. In the homily, it is under her authority, oversight, and goodwill that Christianity, a religion practiced by Roman merchants at the borders of her kingdom, is institutionalized. It is under her watch that a particularly Ethiopian form of Christianity emerges. Through this particular construction of collective memory, the homily hearkens to the past "filtered and shaped through the needs of the present," ${ }^{\prime 2}$ and the story of Frumentius maintains the capacity to function as a tale of local and global proportions in the Ethiopian Christian imagination.

\section{List of References}

Andersen, Knud Tage. "The Queen of the Habasha in Ethiopian History, Tradition and Chronology." Bulletin of the School of Oriental and African Studies 63, no. 1 (20oo): 31-63.

Bausi, Alessandro. "La tradizione scrittoria etiopica." Segno e Testo 6 (2008): 507-557.

Bausi, Alessandro and Alberto Camplani, "New Ethiopic Documents for the History of Christian Egypt." Zeitschrift für antikes Christentum 17, no. 2 (2013): 215-247.

Berger, Iris and E. Frances White. Women in Sub-Saharan Africa: Restoring Women to History. Bloomington and Indianapolis: Indiana University Press, 1999.

Black, Stephanie L. "In the Power of the Christian God Christ': Greek inscriptional evidence for the anti-Arian theology of Ethiopia's first Christian king." Bulletin of the School of Oriental and African Studies 71, no. 1 (2009): 93-110.

51 Getatchew Haile, "Homily," 318. Frumentius' impact is emphasized at the close of the homily (ibid., 318), where Villa observes another parallel with Socrates (Villa, "Frumentius," 93-94).

52 Fine, "Rumor," 7. 
Conti Rossini, Carlo. Storia d'Etiopia. Parte Prima. Dalle Origini all'avvento della Dinastia Salomonide. Bergamo: Istituto Italiano d'Arti Grafiche, 1928.

Crummey, Donald. "Church and Nation: The Ethiopian Orthodox Täwahedo Church (from the Thirteenth to the Twentieth Century)." In Eastern Christianity, edited by Michael Angold, 457-487. Cambridge: Cambridge University Press, 2006. DoI: https://doi.org/10.1017/CHOL9780521811132.020.

Crummey, Donald. Land and Society in the Christian Kingdom of Ethiopia:From the Thirteenth to the Twentieth Century. Urbana: University of Illinois Press, 2000.

Dégh, Linda. "What Is A Belief Legend?" Folklore 107 (1996): 33-46.

Dinkler, Erich. "New Questions concerning King Ezana of Axum." Études et travaux 9 (1976): 6-15.

Dombrowski, Bruno W. and Franz A. Dombrowski. "Frumentius/Abbā Salāmā: Zu den Nachrichten über die Anfänge des Christentums in Äthiopien." Oriens Christianus 68 (1984): 114-169.

Fiaccadori, Gianfranco. "Sembrouthes 'gran re' (DAE IV 3 = RIÉth 275). Per la storia del primo ellenismo aksumita." La Parola del Passato 59 (2004): 103-157.

Fiaccadori, Gianfranco. "Sälama (Käśate Bərhan)." In EAe 4 (2010): 484-488.

Fine, Gary Alan. "Rumor, Trust and Civil Society: Collective Memory and Cultures of Judgment." Diogenes 54, no. 1 (2007): $5^{-18 .}$

Fridman, Iosif. "The Aksumite Kingdom in the Lives of Aksumite Saints." In Veneration of Saints in Christian Ethiopia: Proceedings of the International Workshop Saints in Christian Ethiopia: Literary Sources and Veneration, Hamburg, April 28-29, 2012, edited by Denis Nosnitsin, 51-66. Wiesbaden: Harrassowitz, 2015.

Gelasius of Caesarea. Ecclesiastical History: The Extant Fragments with an Appendix containing the Fragments from Dogmatic Writings, edited by Martin Wallraff, Jonathan Stutz and Nicholas Marinides, translated by Nicholas Marinides. Berlin: De Gruyter, 2018.

Getatchew Haile. "An Anonymous Homily in Honor of King Gllä Aṣbäḥa of Axum. EMML 1763, ff. 34 ${ }^{\mathrm{v}}-35^{\mathrm{v}}$." Northeast African Studies 3, no. 2 (1981): 25-37.

Getatchew Haile. "The Homily in Honour of St. Frumentius Bishop of Axum (EMML ${ }_{1763} \mathrm{ff} .84^{\mathrm{v}}-86^{\mathrm{r}}$ )." Analecta Bollandiana 97, no. 3 (1979): 309-318.

Haas, Christopher. "Mountain Constantines: The Christianization of Aksum and Iberia," Journal of Late Antiquity 1, no. 1 (2008): 101-126.

Hahn, Wolfgang. "Ezanas and Caleb, the Pair of Saintly Kings," in Proceedings of the Xvth International Conference of Ethiopian Studies (Hamburg 2003), edited by Siegbert Unlig, 26o-265. Wiesbaden: Harrassowitz, 2006.

Hummel, Susanne. "The Disputed Life of the Saintly Ethiopian Kings 'Abrəhā and 'Așbəha." Scrinium 12, no. 1 (2016): 35-72. DoI: https://doi.org/10.1163/18177565-0o121 po6.

Humphries, Mark. “Rufinus's Eusebius: Translation, Continuation, and Edition in the 
Latin Ecclesiastical History," Journal of Early Christian Studies 16, no. 2 (2008): 143164.

Kaplan, Steven. "Dominance and Diversity: Kingship, Ethnicity, and Christianity in Orthodox Ethiopia." Church History and Religious Culture 89, no. 1 (2009): 291-305.

Kaplan, Steven. “Ezana's Conversion Reconsidered." Journal of Religion in Africa 13, no. 2 (1982): 101-109.

Kaplan, Steven. "Hagiographies and the History of Medieval Ethiopia." History in Africa 8 (1981): 107-123.

Levine, Donald N. "Evolutionary Grades within Complex Societies: The Case of Ethiopia." In Social Theory and Regional Studies in the Global Age, edited by Said Amir Arjomand, 221-266. Albany: sunY Press, 2014.

Marrassini, Paolo. Storia e leggenda dell'Etiopia tardoantica. Le iscrizioni reali aksumite. Brescia: Paideia, 2014.

Munro-Hay, Stuart C. Aksum, An African Civilization of Late Antiquity. Edinburgh: Edinburgh University Press, 1991.

Munro-Hay, Stuart C. Ethiopia and Alexandria: The Metropolitan Episcopacy of Ethiopia. Warszawa: ZAŚ PAN, 1997.

Phillipson, David W. Foundations of an African Civilization: Aksum \& the Northern Horn 100о BC-AD 1300. Woodbridge: Suffolk Curry, 2014.

Piovanelli, Pierluigi. "The Apocryphal Legitimation of a 'Solomonic' Dynasty in the Kəbrä nägäśt-A Reappraisal," Aetheopica 16 (2013): 7-44.

Piovanelli, Pierluigi. "Reconstructing the Social and Cultural History of the Aksumite Kingdom:Some Methodological Reflections," in Inside and Out:Interactions Between Rome and the Peoples on the Arabian and Egyptian Frontiers in Late Antiquity, edited by Jitse H.F. Dijkstra and Greg Fischer, 329-35o. Leuven: Peeters, 2014.

Robertson, Archibald, ed. Select Writings and Letters of Athanasius, Bishop of Alexandria. Grand Rapids: William B. Eerdmans, 1953.

Rohrbacher, David. The Historians of Late Antiquity. London: Routledge, 2002.

Rufinus of Aquileia. The Church History of Rufinus of Aquileia: Books 10 and 11 , translated by Philip R. Amidon. Oxford: Oxford University Press, 1997.

Rukini, Rugare. "Negus Ezana: Revisiting the Christianisation of Aksum." Verbum et Ecclesia 42, no. 1 (2021). DoI: https://doi.org/10.4102/ve.v42i1.2083.

Schaff, Philip, ed. Theodoret, Jerome, Gennadius, and Rufinus: Historical Writings. Grand Rapids: William B. Eerdmans, 1989.

Socrates Scholasticus. The Ecclesiastical History of Socrates Scholasticus, edited by Andrew Zenos. Grand Rapids: William B. Eerdmans, 1957.

Taddesse Tamrat. Church and State in Ethiopia:1270-1527. Oxford: Clarendon Press, 1972. Villa, Massimo. "Frumentius in the Ethiopic Sources: Mythopoeia and Text-Critical Considerations." Rassegna di Studi Etiopici, Serie terza, 48, no. 1 (2017): 87-111. 